\title{
Relative Study for the Determination of Calcium and Magnesium in Milk Samples by using Complexometric EDTA Titration and FAAS
}

\author{
M. E. Shelke ${ }^{1}$, R.R.Sheikh ${ }^{2}$ \\ ${ }^{1}$ Associate Professor, Department of Chemistry, Institute of Science, Nagpur MS \\ ${ }^{2}$ PG Student, Department of Chemistry, Institute of Science, Nagpur MS \\ *Corresponding Author E-Mail: meshelke@ rediffmail.com
}

\begin{abstract}
Milk is primary source of nutrition. It contains vitamins, fats, carbohydrates, proteins, minerals like Calcium and Magnesium and many more. The aspire of the present study to accepted out the determination of amount of calcium and magnesium in milk samples collected from different locations. After handling, a relative study was carried out for the determination of calcium and magnesium in milk. The calcium and magnesium content of the digest were determined using flame atomic absorption spectrophotometer $(F A A S)$ and the complexometric titrations with EDTA by using Erichrome Black-T indicator. The present study gives a new image on concentrations of calcium and magnesium in milk as a result of different environmental conditions such as site, feeding plants.
\end{abstract}

Keywords: Calcium, Magnesium, Complexometric titration, Atomic Absorption Spectrometry.

\section{Introduction:}

Milk has been accepted worldwide as an excellent supply of healthy nutrition for the human body alone or in mixture with other foods or water, fat, lactose, protein and mineral matter. The different elements present in milk plays a significant role in human growth ${ }^{1}$. The composition of milk is largely affected by the type of animal feed and contamination of soil. It is an excellent source of calcium and can supply moderate amounts of magnesium, iron, zinc and copper ${ }^{2-4}$. However, due to an increase in environmental pollution, it is essential to find out the level of harmful metals in milk, as they have undesirable effects on human health. Calcium contributes to structural functions in teeth and bones along with regulating many biological functions.

Recently, focus on calcium has important role in preventing osteoporosis ${ }^{5}$. Magnesium is the richest cation in the human body after sodium, potassium and calcium. Mostly the magnesium is deposited in bones. ${ }^{6}$ This work combines with analysis by using complexometric titration with EDTA $^{7}$ and flame atomic absorption spectroscopy for the determination of calcium and magnesium from milk samples of cow and buffalo of different locations. Values obtained were compared to WHO limits ${ }^{8}$.

\section{Experimental:}

All reagents used were of analytical grade. Distilled water was used for the preparation of all solutions. Eriochrome Black- ${ }^{9}$ was prepared by using ethanol, as an indicator while ethylene diamine tetreacetic acid ${ }^{9}$ (EDTA) was used as a complexing agent. An alkaline buffer of ammonium chlorideammonia having $\mathrm{pH} 10$ was used to maintain $\mathrm{pH}$.

\section{Preparation of Sample Solutions:}

The milk samples of cow and buffalo were collected from different locations in clean and covered previously washed stainless steel bottles, and have been kept at $5^{\circ} \mathrm{C}$ until to prepare the sample solutions $^{10} .5 \mathrm{ml}$. of each milk sample were taken in the volumetric flask and $50 \mathrm{ml}$. of $24 \%$ TCA were 
added for the digestion of milk sample. Shaken the samples at 5 minutes interval for 30 minutes, and then centrifuge each sample for 5 minutes at $4000 \mathrm{rpm}$. Filtered each sample with filter paper and then transfer a $5-\mathrm{mL}$ aliquot of the filtrate to a $50 \mathrm{~mL}$ volumetric flask, $1 \mathrm{~mL}$ of $5 \%(\mathrm{w} / \mathrm{v})$ lanthanum solution were added in it, and make to volume with distilled water. Preserved this in the stopper bottle then forward it for the Atomic Absorption analysis.

\section{Instrumentation:}

Atomic Absorption Spectrometer Model AA300, M/S PERKIN ELMER, USA was used for the determination of calcium and magnesium in different milk samples. The samples were run in triplicate.

Table 1: Working parameters - standard conditions for PERKIN ELMER, USA Atomic Absorption Spectrophotometer (Model AA300).

\begin{tabular}{|c|c|c|c|c|c|c|c|c|c|}
\hline Metal & $\begin{array}{l}\text { Wavelength } \\
(\mathbf{n m})\end{array}$ & $\begin{array}{c}\text { Slit } \\
\text { width } \\
(\mathbf{n m})\end{array}$ & $\begin{array}{c}\text { Time } \\
\text { constant } \\
(\mathrm{s})\end{array}$ & $\begin{array}{c}\text { Lamp } \\
\text { current } \\
(\mathbf{m A})\end{array}$ & Atomizer & $\begin{array}{l}\text { Flame } \\
\text { type }\end{array}$ & $\begin{array}{c}\text { Fuel } \\
\text { flow } \\
\text { (1/min) }\end{array}$ & $\begin{array}{c}\text { Oxidant } \\
\text { (kPa) }\end{array}$ & $\begin{array}{c}\text { Burner } \\
\text { height } \\
(\mathbf{m m})\end{array}$ \\
\hline $\mathbf{C a}$ & 422.7 & \multirow{2}{*}{0.7} & \multirow{2}{*}{1.0} & \multirow{2}{*}{9.0} & \multirow{2}{*}{ Standard } & Air- & \multirow{2}{*}{2.7} & \multirow{2}{*}{160} & \multirow{2}{*}{7.5} \\
\hline Mg & 285.2 & & & & & $\mathrm{C}_{2} \mathrm{H}_{2}$ & & & \\
\hline
\end{tabular}

\section{Determination of Calcium in Milk by Complexometric EDTA Titration}

$10 \mathrm{ml}$ of sample was taken in a conical flask and 2-3 pellets of $\mathrm{KOH}$ were added. After shaking the solution few drops of Eriochrome Black T indicator was added and the samples were titrated against $0.01 \mathrm{M}$ EDTA solution until a color change from wine red to sky blue.

\section{Determination of Magnesium in Milk by Complexometric EDTA Titration}

$10 \mathrm{ml}$ of sample was taken in a conical flask and $4-5 \mathrm{ml}$ of buffer solution was added followed by 2-3 drops of Eriochrome Black T indicator. The samples were then titrated against 0.01M EDTA solution until the color changed from wine red to sky blue.

\section{Results and Discussion:}

\section{Calcium:}

The concentration of calcium in cow milk from different locations is ranging from 1040-1204 $\mathrm{mg} / \mathrm{kg}$ while in buffalo milk it is ranging from $1586-1901 \mathrm{mg} / \mathrm{kg}$ as determined by FAAS. The concentration of Calcium in cow milk from different locations is ranging from 700-1250 mg/lit while in buffalo milk it is ranging from 1120-1300 mg/lit as determined by EDTA titration complexometrically.

\section{Magnesium:}

The concentration of magnesium in cow milk is ranging from $895-1219 \mathrm{mg} / \mathrm{kg}$ and in buffalo milk it is ranging from $1227-1331 \mathrm{mg} / \mathrm{kg}$ as determined by FAAS while it is ranging from $604-650 \mathrm{mg} / \mathrm{lit}$ in cow milk and 765-1350 mg/lit in buffalo milk collected from different locations as determined by EDTA titration complexometrically.

Table 2: Analysis of metals by FAAS analysis

\begin{tabular}{|c|c|c|c|c|c|c|}
\hline Locations & \multicolumn{2}{|c|}{ NS } & \multicolumn{2}{c|}{ KT } & \multicolumn{2}{c|}{ NW } \\
\hline Metals & Cow & Buffalos & Cow & Buffalos & Cow & Buffalos \\
\hline $\mathrm{Ca}$ & 1134 & 1586 & 1204 & 1901 & 1040 & 1692 \\
\hline $\mathrm{Mg}$ & 903 & 1331 & 1219 & 1493 & 895 & 1227 \\
\hline
\end{tabular}


Table 3: Analysis of metals by EDTA complexometric method

\begin{tabular}{|c|c|c|c|c|c|c|}
\hline Locations & \multicolumn{2}{|c|}{ NS } & \multicolumn{2}{c|}{ KT } & \multicolumn{2}{c|}{ NW } \\
\hline Metals & Cow & Buffalos & Cow & Buffalos & Cow & Buffalos \\
\hline $\mathrm{Ca}$ & 700 & 1300 & 1250 & 1700 & 960 & 1120 \\
\hline $\mathrm{Mg}$ & 650 & 1350 & 650 & 1100 & 604 & 765 \\
\hline
\end{tabular}

\section{Conclusion:}

The present study was performed to estimate the association between element concentrations in the milk of grazing animals and city animals in order to underline the effect of the environmental conditions on element concentrations in milk. The analysis reveals the presence of calcium and magnesium in milk of KT in higher concentrations than in cow and buffalo milk from NS and NW. The grazing cow and buffalo milks contain higher concentrations of elements than those from the city, depending on the higher element concentrations in grazing plants.

\section{Acknowledgements:}

The Authors are very thankful to Head of Chemistry Department, Institute of Science, Nagpur for providing laboratory facilities to perform the experimental works. The Authors are also thankful to Incharge Central Instrumentation Cell, Sant Gadge Baba Amravati University, Amravati for providing facility of Atomic Absorption Spectroscopy.

\section{References:}

[1] Belewu M. A. and Aiyegbusi O. F. (2002). Comparison of the mineral content and apparent biological value of milk from human, cow and goat. J. Food Tech. Africa. 7(1): 9-11.

[2] Levy Y, Zeharoa A, Grunebaum M, Nitzan M, Steinherz R. Copper deficiency in infants food fed cow milk. J. Pediat. 106:786-788, 1985.

[3] Imran M., Khan, H., Hassan, S. S. and Khan R. (2008). Physicochemical characteristics of various milk samples available in Pakistan. J. Zhejiang Univ. Sci. 9(7): 546-551.

[4] Pennigton J, Wilson D, Young B, Johnson R, Vanderveen J. Mineral content of market samples of whole milk. J. Am. Diet. Assoc. 87:1036-1042, 1987.

[5] Mahan L, Stump S, Alimentos, Nutricao and Dietuterapia, Roca, Sao Paulo, 2002.

[6] Civitelli R, Avioli L. Calcium, phosphate and magnesium absorption In: Johnson LR ed. P h y s i o 1 o g y o f t h e Gastrointestinal tract, 3rd ed. Raven Press, New York, 1994.

[7] Pingle S.A., Pawar V.R. and Bhagde R.V., Trends in Life Sciences, Volume- 5 Issue- 3, 2016 pp $1-3$

[8] Jorhem L. Determination of metals foodstuff by atomic absorption spectrometry after dry ashing: NMKL1 inter-laboratory study of lead, cadmium, zinc, copper, iron, chromium and nickel. J. AOAC Inter. 76:798-813, 1993.

[9] Zaib Hussain, Ammara Nazir, Umer Shafique, Muhammad Salman, Journal of Scientific Research Vol. XXXX No. 1, June, 2010 pp 9-14.

[10] "Determination of Metals in Milk." FP-11. Perkins-Elmer AAS Manual. 